\title{
Preparation of Cell-free Bacterial Extracts with Powdered Alumina
}

\author{
By H. McILWAIN \\ Unit for Research in Cell Metabolism (Medical Research Council), \\ Department of Biochemistry, University of Sheffield
}

SUMMARY: A commercially available powdered alumina is very suitable for breaking bacterial cells according to the method of Wiggert, Silverman, Utter \& Werkman (1940). Extracts have been prepared from streptococci in this way, which are capable of glycolysis', the deamination of adenosine diphosphate, and the production of $\mathrm{NH}_{3}$ from arginine.

In using the method of Wiggert, Silverman, Utter \& Werkman (1940) for preparing bacterial extracts by rubbing with powdered glass, the major operation at present is the preparation of the powdered glass, which is required in particles about the size of the bacterial cells. A preparation of alumina marketed as a fine abrasive for metallographic work was observed to consist of particles of about the size required, and has been found very suitable for breaking the cells of several bacterial species.

It was also found in at least one case that enzymically more active extracts were obtained by using the alumina than by using powdered glass. The powder added may well adsorb components from the cells which it breaks. The introduction of alumina for this purpose, therefore, has the advantage of introducing an agent which differs from glass in its adsorbing powers, as well as being easily available.

Whether the enzyme systems extracted were in true solution was not determined, but any particles with which they may have been associated were not resolved by a $\frac{1}{12}$ in. objective and hence were much smaller than the bacterial cells.

\section{EXPERIMENTAL AND RESULTS}

Alumina. Griffin and Tatlock's 'Microid Polishing Alumina', grade 3/50 ('slow cutting') was supplied as an aqueous suspension. It was centrifuged, the precipitate washed once with water, spread in the tube or on a dish and dried at $100^{\circ}$. This yielded a porous, friable solid, a little softer than blackboard chalk, which was not dusty and which could be handled without the precautions necessary in handling finely powdered glass. It was much more uniform in particle size than glass prepared according to Wiggert et al. (1940).

Breakage of cells. The procedure below is suitable for handling $0 \cdot 4-3 \mathrm{~g}$. moist weight of bacterial cells in 5-15 ml. centrifuge tubes, though the method is not likely to be limited to these quantities. Cells were collected by centrifuging in a tared tube, washed once, drained well from adhering liquid, weighed, and 2.5 times their weight of dried alumina added. The tube was cooled in ice-water, its contents mixed well with a glass rod to yield a dry powder, which was transferred to a cooled mortar. It was rubbed with a cooled pestle with 
maximum hand pressure for 30 sec., scraped together as it mounted the sides of the mortar, and the rubbing repeated. Indication of satisfactory breaking of the cells was given by the mixture darkening in colour and becoming moister. It was transferred (spatula) to a fresh, cooled centrifuge tube, the mortar and pestle washed with extracting solution, the washing added to the tube, and the whole mixed well and centrifuged. This yielded layers of the alumina below, a yellow juice above, and one or more layers of cell debris between. Separation of the grinding agent from the cell debris was much sharper with alumina than with glass powder, presumably because the alumina had been prepared in uniform particle size.

Degree of cell breakage. The fraction of cells broken by treatment was estimated by comparing the ratio of cells to alumina particles, before and after rubbing. Duplicate slides were made carrying in films of water $(a)$ a specimen of the initial mixture and $(b)$ a specimen after rubbing. These were dried, fixed, stained with methylene blue or by Gram's method and examined in cedar-wood oil or a substitute of similar refractive index. The alumina particles were then visible. In such preparations, glass particles are invisible, but similarly prepared slides with glass particles can be examined in water. The numbers of intact bacteria and of alumina particles in suitable fields of the four films were then counted. Reasonable agreement between the duplicates was found, provided the initial mixing had been thorough, fixing adequate, and blotting avoided in drying the slides. The bacteria apparently provided adequate anchoring material for the alumina particles. Gram-positive organisms were seen extremely sharply after partial breakage and Gram staining, against a background of unresolved (by $\frac{1}{12}$ in. objective) Gram-positive material and colourless alumina. Cells 'dented' or partly damaged by the alumina were only occasionally seen.

It is easy to break over $99 \%$ of the cells of streptococcal preparations in this way. Breakage was most commonly less complete when the initial centrifuged mass of bacteria was too moist through inadequate centrifuging or draining from mother-liquor after centrifuging, though considerable latitude was permissible in these factors. Thus, preparations of moist weight/dry weight ratios between 6 and 9 were adequately broken when the ratios of alumina weight/moist bacterial weight were 2.5 to 3 . With practice it is possible to add 2.5 times the bacterial weight of alumina, and to judge by the consistency of the mixture whether more alumina is likely to be needed: in the desirable consistency the mixture seems dry and can be moulded to shape, though it is more friable than would be desired for modelling It is, further, possible to tell by the 'feel' and appearance during rubbing with the pestle, whether breakage is occurring, and more alumina can if necessary be added at this stage Excess alumina rarely prevented breakage, but made the later extraction less complete.

\section{Enzyme activity of cell extracts}

Glycolysis in an extract from haemolytic streptococci. Cells of a $\beta$-haemolytic streptococcus (strain 'Richards', N.C.T.C. no. 5631), of wet weight 0.43 g. and wet weight/dry weight ratio $7 \cdot 5$, were broken with $1 \cdot 1 \mathrm{~g}$. alumina. The product was rubbed up with $0.85 \mathrm{ml}$. of a cold mixture of equal vol. of $0.05 \mathrm{M}$ phosphates, 
pH 7.0 and a yeast extract (made by boiling baker's yeast with its own weight of water for $15 \mathrm{~min}$., cooling and taking to $\mathrm{pH} \mathrm{7)}$ ). The mixture was immediately centrifuged in a tube packed in ice ('Bara' centrifuge, 5 min.). Warburg vessels had been prepared with reagents sufficient to give final concentrations of $\mathrm{NaHCO}_{3}, 0.03 \mathrm{M}$; glucose, $0.05 \mathrm{M}$; hexosediphosphate, $0.02 \mathrm{M}$. The extract $(0.24 \mathrm{~g}$., equivalent to $17 \mathrm{mg}$. dry weight of streptococci) was added, yellow phosphorus placed in a centre well, $\mathrm{N}_{2}+5 \% \mathrm{CO}_{2}$ passed, the solution equilibrated at $37^{\circ}$, and readings commenced $7 \mathrm{~min}$. after placing at $37^{\circ}(40 \mathrm{~min}$. after grinding the cells). $\mathrm{CO}_{2}$ evolution was linear during the period of $7-80 \mathrm{~min}$. at $37^{\circ}$, and at the rate of $14 \mu \mathrm{mol} . / \mathrm{hr}$. Chemical determinations (Friedemann \& Graeser, 1933) showed over $85 \%$ of this to be due to the formation of lactic acid. This rate of glycolysis represented about $10 \%$ of the activity of the intact cells, and so compared favourably in activity with glycolyzing extracts from other bacterial cells. Extracts prepared from streptococci by ground glass were markedly less active. Other extracts prepared with alumina had $8-12 \%$ of the activity in suspensions which contained less than half of the dry weight of the cells.

When glutamine $(0.01 \mathrm{M})$ was added to a reaction mixture similar to that detailed above and containing a portion of the same streptococcal extract, additional $\mathrm{NH}_{3}$ was found to be produced at the rate of $0 \cdot 15 \mu \mathrm{mol} . / \mathrm{mg}$.equiv. of juice/hr. during the glycolysis. This rate is also about one-tenth of that of the reaction in intact cells (cf. Mcllwain, 1946).

Deamination of adenosine diphosphate. Streptococci (Richards's strain) were broken with alumina and extracted with twice their moist weight of $0.05 \mathrm{M}$

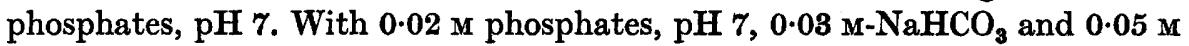
adenosine diphosphate in an atmosphere of $5 \% \mathrm{CO}_{2}$ in $\mathrm{N}_{2}$ (yellow phosphorus in a centre well), $\mathrm{NH}_{3}$ was evolved at the rate of $0.25 \mu \mathrm{mol} . / \mathrm{mg}$.-equiv. of cells $/ \mathrm{hr}$. When adenosine diphosphate $(0.05 \mathrm{M})$ was added to a glycolyzing streptococcal extract prepared and reacting under the conditions of the preceding section, additional $\mathrm{NH}_{3}$ was formed at the rate of $0.5 \mu \mathrm{mol} . / \mathrm{mg}$.equiv. of juice/hr.

Arginine dihydrolase. Preparations were made from streptococcal strains, by extracting 3 times with $0.6 \% \mathrm{NaCl}$ twice the moist volume of the cells. Reaction (cf. Hills, 1940) was carried out with the extract in $0.04 \mathrm{M}$ phosphate, $\mathrm{pH} 7$, containing arginine, $0.05 \mathrm{~m}$. With the $R$ strain, $\mathrm{NH}_{3}$ was evolved at the rate of $0.5 \mu \mathrm{mol} . / \mathrm{mg}$.-equiv, dry wt. $/ \mathrm{hr}$. This is about one-third of the total cell activity, but the $\mathrm{pH}$ optimum of the enzyme has not been fully investigated. It corresponded to $85 \mu \mathrm{mol} . / \mathrm{g}$. of liquid extract/hr. Activity was lost on heating at $100^{\circ}$ for a few minutes.

\section{Repeated use of powdered alumina}

Under some circumstances the alumina may with advantage be used repeatedly. The following two methods were tried, using it for extracting arginine dihydrolase.

The deposit of alumina after grinding and extracting streptococci was washed once by centrifuging, suspended in $5 \mathrm{vol}$. conc. $\mathrm{HNO}_{3}$, taken to dryness 
in a silica basin and then to red heat. Ignition left a light grey powder, still in particles of about the original size and shape. This was used for the breakage of streptococci, which followed its usual course: but the juice obtained on extraction was without arginine dihydrolase activity. The absorptive properties of the alumina with respect to the enzyme had presumably been changed; it was not further examined.

The deposit of alumina after grinding was washed twice with water, spread and dried at $100^{\circ}$, and used in the standard manner for extracting arginine dihydrolase from a second portion of the batch of streptococci used initially. The extract showed about $1 \cdot 3$ times the activity obtained from the first portion. Recovery was repeated and yielded again a juice of slightly higher activity. In this case cell constitutents from the earlier extractions presumably remained attached to the alumina and reduced the absorption in later extracts.

I am greatly indebted to Mr D. E. Hughes for assistance during this work, and to Mrs M. Bielschowsky for a gift of adenosine diphosphate.

\section{REFERENCES}

Friedemann, T. E. \& Graeser, J. B. (1933). The determination of lactic acid. J. biol. Chem. 100, 291.

Hrus, G. M. (1940). Ammonia production by pathogenic bacteria. Biochem. J. 34, 1057.

McIlwaIN, H. (1946). Ammonia formation from glutamine by haemolytic streptococci. Biochem. J. 40, 67.

Wiggert, W., Silverman, M., Utter, M. F. \& Werkman, C. H. (1940). Preparations of an active juice from bacteria. Iorwa St. Coll. J. Sci. 14, 179. 